\title{
PENGARUH UPAH MINIMUM DAN DISITRIBUSI PENDAPATAN TERHADAP JUMLAH PENDUDUK MISKIN JAWA TIMUR
}

\author{
Satria Yuda Anggriawan \\ PT. Mega Finance \\ Dr. ArisSoelistyo, M.Si \\ Dra. DwiSusilowati, M. M. \\ Fakultas Ekonomi dan Bisnis Universitas Muhammadiyah Malang \\ Email: satriayudaa1993@gmail.com
}

\begin{abstract}
This study aims to determine the relationship between the minimum wage and the income distribution of the poor. This research is a quantitative research using panel data, data used in the form of time series (2010-2014) and cross-section (29 districts and 9 cities in East Java). The data used in this study are secondary data obtained from the Central Statistical Agency (BPS) and the journal as a supporter. The analytical method used is the linear regression analysis of data using the software toolbox used common effect EViews 6. The results showed that the number of poor people in the neighborhood / city in the East Java period 2010-2014 decreased in An average of 5,088,144, minimum wage positive and significant variable impact on poverty and income distribution and a significant positive effect on the number of poor people in the neighborhood / city in East Java province.
\end{abstract}

Keywords: Number of poor, minimum wage and income distribution in the District / City

\begin{abstract}
ABSTRAK
Penelitian ini bertujuan untuk mengetahui hubungan antara variabel Upah Minimum dan Distribusi Pendapatan terhadap jumlah penduduk miskin. Penelitian ini merupakan penelitian kuantitatif dengan menggunakan data panel, data yang digunakan berupa time series (tahun 2010-2014) dan cross section (29 Kabupaten dan 9 Kota di Provinsi Jawa Timur). Jenis data yang digunakan dalam penelitian ini adalah data sekunder yang diperoleh dari Badan Pusat Statistik (BPS) dan jurnal sebagai pendukung. Metode analisis yang digunakan adalah metode analisis regresi linier data panel dengan metode Common Effect digunakan alat bantu software Eviews 6. Hasil penelitian menunjukkan bahwa jumlah penduduk miskin di Kabupaten/Kota di Jawa Timur dari tahun 2010-2014 mengalami penurunan dengan rata-rata sebesar 5,088.144, variabel upah minimum berpengaruh positif dan signifikan terhadap jumlah penduduk miskin dan distribusi pendapatan berpengaruh positif dan signifikan terhadap jumlah penduduk miskin di Kabupaten/Kota di Provinsi Jawa Timur.

Kata kunci: Jumlah penduduk miskin, Upah Minimum dan Distribusi Pendapatan di Kabupaten/Kota
\end{abstract}


PENDAHULUAN

Pembangunan adalah suatu proses dinamis yang bertujuan meningkatkan kesejahteraan masyarakat. Tolak ukur keberhasilan pembangunan dapat dilihat dari pertumbuhan ekonomi, struktur ekonomi, dan semakin kecilnya kesenjangan pendapatan antar penduduk, antar daerah dan antar sektor. Tujuan utama dari usahausaha pembangunan ekonomi selain menciptakan pertumbuhan yang setinggi-tingginya, harus pula menghapus atau mengurangi tingkat kemiskinan, kesenjangan pendapatan, dan tingkat pengangguran (Todaro, 2000). Oleh sebab itu, prioritas pembangunan adalah menghapuskan kemiskinan.

Kemiskinan merupakan salah satu masalah sosial yang ada di Indonesia. Jawa Timur khususnya yang juga tidak lepas dari masalah kemiskinan. Kemiskinan merupakan suatu keadaan dimana seseorang tidak sanggup untuk memenuhi kebutuhanya sendiri sesuai dengan taraf kehidupan lingkungannya sehingga seseorang tersebut mengalami kesengsaraan dalam hidupnya. Variabel kemiskinan sangat beragam, antara lain rendahnya tingkat pendidikan, dan banyaknya masyarakat.

Menurut (Arsyad; 1999) ada dua lingkaran perangkap kemiskinan, yaitu dari segi penawaran (supply) dimana tingkat pendapatan masyarakat yang rendah yang diakibatkan oleh tingkat produktivitas yang rendah menyebabkan kemampuan masyarakat untuk menabung rendah. Kemampuan untuk menabung rendah, menyebabkan tingkat pembentukan modal yang rendah, tingkat pembentukan modal (investasi) yang rendah menyebabkan kekurangan modal, dan dengan demikian tingkat produktivitasnya juga rendah dan seterusnya. Dari segi permintaan (demand), di negara-negara yang miskin perangsang untuk menanamkan modal adalah sangat rendah, karena luas pasar untuk berbagai jenis barang adanya terbatas, hal ini disebabkan oleh karena pendapatan masyarakat sangat rendah.

Upah minimum adalah suatu standar minimum yang digunakan oleh para pengusaha atau pelaku 
industri untuk memberikan upah kepada pekerja di dalam lingkungan usaha atau kerja. (Kaufman 2000) tujuan utama ditetapkannya upah minimum adalah memenuhi standar hidup minimum seperti untuk kesehatan, efisiensi, dan kesejahteraan pekerja.

Pengaruh antara Upah

Minimum terhadap kemiskinan dipengaruhi oleh adanya biaya sosial inflasi dimana biaya sosial inflasi membuat seseorang semakin miskin. komplain terhadap inflasi adalah hal yang umum, kita tahu bahwa Kenaikan dalam daya beli tenaga kerja berasal dari akumulasi modal dan kemajuan teknologi. Biasanya upah tak bergantung pada beberapa banyak uang yang di cetak pemerintah. Jika pemerintah menurunkan inflasi dengan memperlambat tingkat pertumbuhan uang. Para pekerja tidak akan melihat upah mereka naik lebih cepat. Padahal ketika inflasi lebih lambat perusahaan atau sedikit menaikkan harga produk mereka setiap tahun dan akibatnya akan memberi para pekerja kenaikan Upah minimum yang lebih kecil. (Waluyo, 2007)
Menurut Todaro (2000), Pengaruh antara ketimpangan distribusi pendapatan terhadap kemiskinan dipengaruhi oleh adanya peningkatan jumlah penduduk. Pertambahan penduduk cenderung berdampak negatif terhadap penduduk miskin, terutama bagi mereka yang sangat miskin. Sebagian besar keluarga miskin memiliki jumlah anggota keluarga yang banyak sehingga kondisi perekonomian mereka yang berada di garis kemiskinan semakin memburuk seiring dengan memburuknya ketimpangan pendapatan atau kesejahteraan.

Tujuan yang akan dicapai dalam penelitian ini adalah untuk mengetahui adanya pengaruh upah minimum dan distribusi pendapatan terhadap jumlah penduduk miskin di Jawa Timur.

\section{METODE PENELITIAN}

Data yang digunakan dalam penelitian ini adalah data upah minimum, distribusi pendapatan dan jumlah penduduk miskin di Kota/Kabupaten Provinsi Jawa Timur hasil survey Badan Pusat Statistik (BPS)..

1. Regresi Linier Berganda 
Pengaruh Upah Minimum dan Distribusi ..(Satria Yuda Anggriawan)

Penelitian ini bersifat $\alpha=$ Konstanta

kuantitatif, sehingga untuk meneliti

$\beta_{1}=$ Koefisien Regresi dari $\mathrm{X}_{1}$

pengaruh upah minimum dan

$\beta_{2}=$ Koefisien Regresi dari $X_{2}$

distribusi pendapatan terhadap

$\mathrm{X}_{1}=$ Upah Minimum

jumlah penduduk miskin, maka

$\mathrm{X}_{2}=$ Distribusi Pendapatan

metode yang digunakan untuk

penelitian ini adalah OLS (Ordinary

Least Square) dengan model regresi

linier berganda dengan data panel. .

Regresi linier berganda atau model

regresi majemuk merupakan suatu model regresi yang terdiri dari atas lebih dari satu variabel independen.

Ada tiga teknik dalam perhitungan regresi linier berganda dengan menggunakan data panel yaitu teknik OLS (Ordinary Least Square), Fixed Effect, dan Random Effect. Perhitungan ini dilakukan dengan menggunakan bantuan aplikasi Eviews9. Dari tiga teknik perhitungan regresi linier berganda dengan menggunakan data panel pemilihan terbaik peneliti disini menggunakan model OLS (Ordinary Least Square)/ Common Effect.

Model regresi linier berganda dengan data panel yang digunakan adalah sebagai berikut :

$\mathrm{Y}_{\mathrm{it}=\alpha} \alpha+\beta_{1} \mathrm{X}_{1 \mathrm{it}}+\beta_{2} \mathrm{X}_{2 \mathrm{it}}+\beta_{3} \mathrm{X}_{3 \mathrm{it}}+\mathrm{e}_{\mathrm{it}}$

Dimana :

$\mathrm{Y}=$ Kemiskinan

$\mathrm{e}_{\mathrm{it}}=$ Term of error

2. GIS (Analisis Sistem Informasi Geografis) (Interval)

Sistem Informasi Geografis (SIG) merupakan kumpulan yang terorganisir dari perangkat keras komputer, perangkat lunak, data geografi, dan personel yang didesain untuk memperoleh, menyimpan, memperbaiki, memanipulasi, menganalisis, dan menampilkan semua bentuk informasi yang bereferensi geografi. (Budiyanto, 2002)

\section{Uji Hipotesis}

a. Uji t

Uji statistik t pada dasarnya menunjukan seberapa jauh pengaruh variabel independen secara individual.

\section{b. Uji F}

Uji F pada dasarnya digunakan untuk membuktikan pengaruh secara bersama-sama statistik bahwa seluruh variabel independen yaitu Upah Minimum dan Distribusi Pendapatan di 
Kabupaten/Kota di Provinsi Jawa

Timur tahun 2010-2014 (Gujarati, 2004:120).

c. $\mathbf{U j i} \mathbf{R}^{2}$

$$
\mathrm{R}^{2} \text { bertujuan untuk }
$$

mengetahui seberapa jauh variasi variabel independen dapat menerangkan dengan baik variasi variabel dependen. Untuk mengukur kebaikan suatu model (goodnes of fit), di gunakan koefisien determinasi $\left(\mathrm{R}^{2}\right)$. Koefisien determinasi $\left(\mathrm{R}^{2}\right)$ merupakan angka yang memberikan proporsi atau persentase variasi total dalam variabel tak bebas (Y) yang di jelaskan oleh variabel bebas (X) (gujarati, 2004: 163).

\section{PEMBAHASAN}

Pemetaan penduduk miskin Kabupaten/Kota di Provinsi Jawa Timur tahun 2010 di gambarkan pada peta yang dapat di lihat pada gambar 1. Pemetaan tersebut menunjukkan jumlah penduduk miskin pada tahun 2010 yang termasuk dalam kategori kelas 1 (satu) dengan tingkat kemiskinan (0,16\%-1,31\%) terdapat pada Kota Blitar, Kota Kediri, Kota Madiun,
Kota Malang, Kota Mojokerto, Kota Pasuruan, Kota Probolinggo, dan Kota Batu.

Kategori kelas 2 (dua) yaitu Blitar, Bondowoso, Madiun, Magetan, Mojokerto, Pacitan, Ponorogo, Situbondo, Trenggalek dan Tulungagung. Yang termasuk kelas 3 (tiga) yaitu Banyuwangi, Gresik, Jombang, Lumajang, Nganjuk, Ngawi, Pamekasan, Pasuruan, Sidoarjodan Surabaya. Sedangkan kategori kelas ke 4 (empat) Bangkalan, Bojonegoro, Kediri, Lamongan, Sumenep, dan Tuban. Yang termasuk kelas ke 5 Jember, Malang, Probolinggo, dan Sampang.

Sedangkan Dari pemetaan gambar 2 jumlah penduduk miskin pada tahun 2011 yang termasuk dalam kelas 1 dengan tingkat kemiskinan $(1,31 \%$ 2,47\%) terdapat pada Kota Blitar, Kota Kediri, Kota Madiun, Kota Malang, Kota Mojokerto, Kota Pasuruan, Kota Probolinggo, dan Kota Batu. Yang termasuk kelas 2 yaitu Blitar, Bondowoso, Madiun, Magetan, Mojokerto, Pacitan, Ponorogo, Situbondo, Trenggalek dan Tulungagung. Yang termasuk kelas 3 yaitu Banyuwangi, Gresik, 
Jombang, Lumajang, Nganjuk,

Ngawi, Pamekasan, Pasuruan,

Sidoarjo dan Surabaya. Yang termasuk kelas ke 4 Bangkalan,
Bojonegoro, Kediri, Lamongan, Sumenep, danTuban. Yang termasuk kelas ke 5 Jember, Malang, Probolinggo, dan Sampang.

\section{Gambar 1. Pemetaan Jumlah Penduduk Miskin Berdasarkan Kelas Interval}

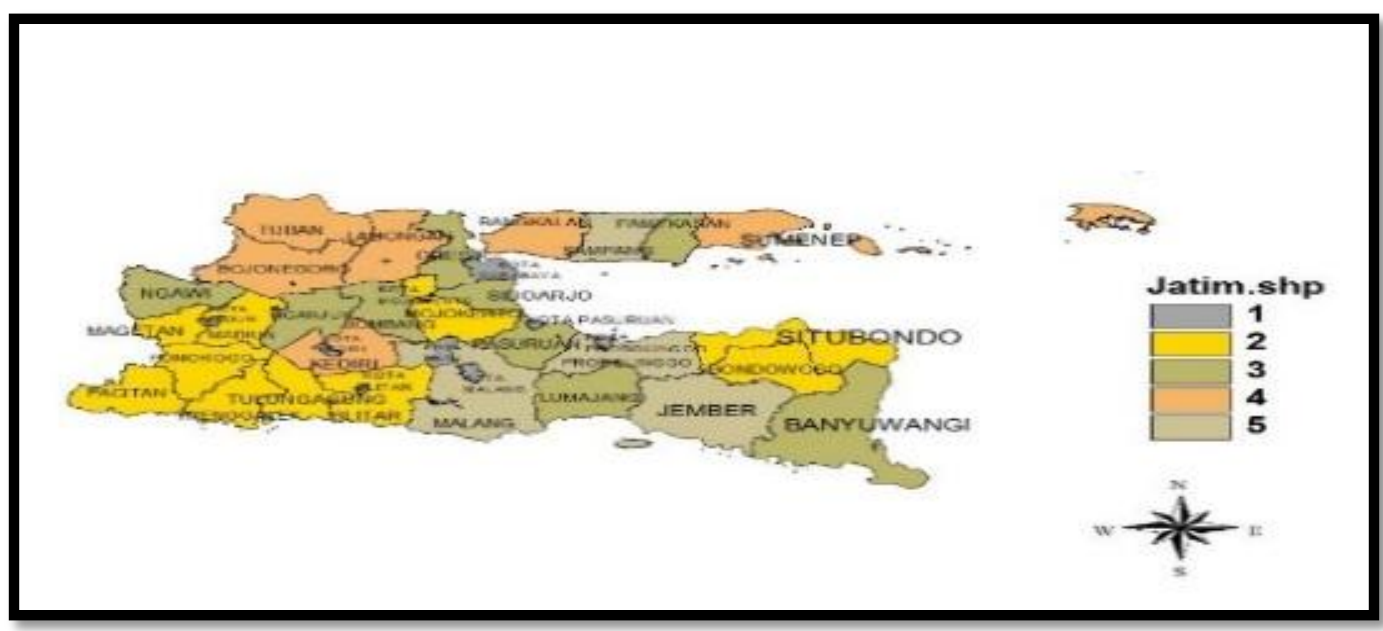

Sumber : Data sekunder diolah, Gis(2016)

Gambar 2. Pemetaan jumlah penduduk miskin berdasarkan kelas interval

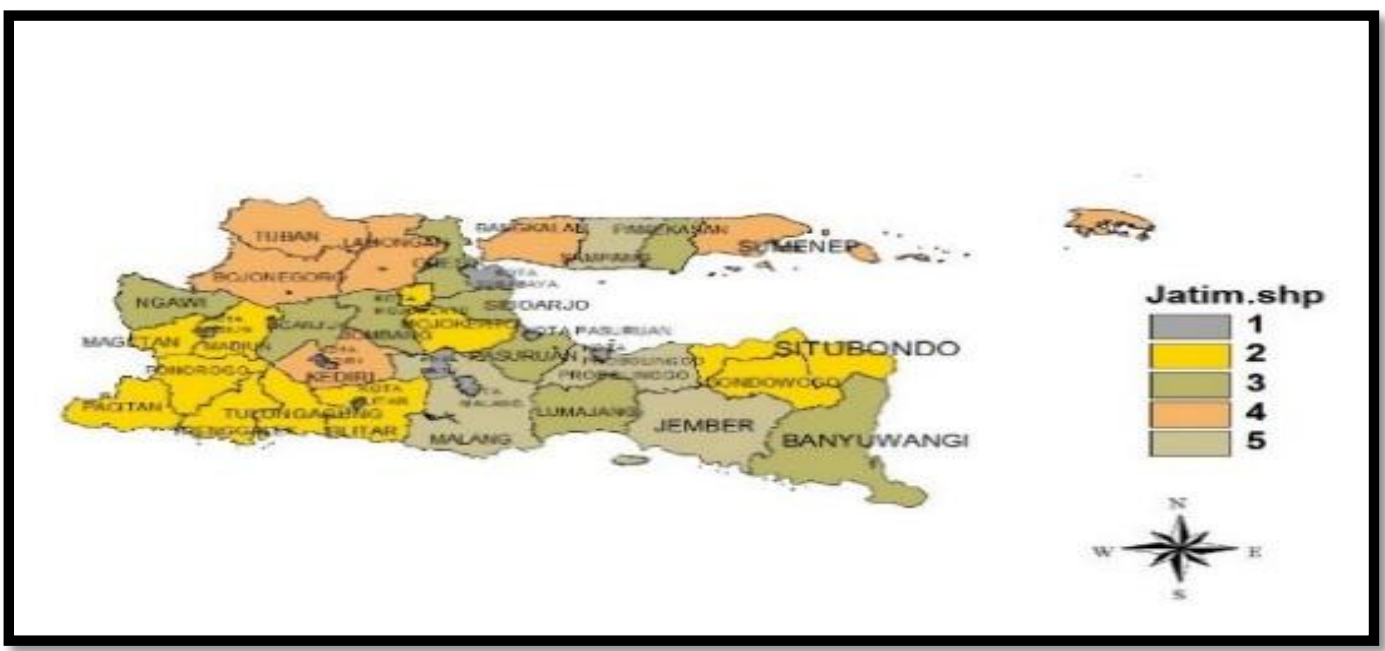

Sumber : Data sekunder diolah, Gis(2016)

Pemetaan penduduk miskin tahun 2012 dapat di gambarkan pada peta gambar 3, dimana yang termasuk dalam kelas 1 dengan tingkat kemiskinan $(2,48 \%-3,36 \%)$ terdapat pada Kota Blitar, Kota
Kediri, Kota Madiun, Kota Malang, Kota Mojokerto, Kota Pasuruan, Kota Probolinggo, dan Kota Batu. Yang termasukkelas 2 yaituBlitar, Bondowoso, Madiun, Magetan, Mojokerto, Pacitan, Ponorogo 
Pengaruh Upah Minimum dan Distribusi ..(Satria Yuda Anggriawan)

Situbondo, Trenggalek dan Surabaya. Yang termasuk kelas ke 4 Tulungagung. Yang termasuk kelas 3 Bangkalan, Bojonegoro, Kediri, yaitu Banyuwangi, Gresik, Jombang, Lamongan, Sumenep, danTuban. Lumajang, Nganjuk, Ngawi, Yang termasuk kelas ke 5 Jember, Pamekasan, Pasuruan, Sidoarjo dan Malang, Probolinggo, dan Sampang.

Gambar 3. Pemetaan jumlah penduduk miskin berdasarkan kelas interval

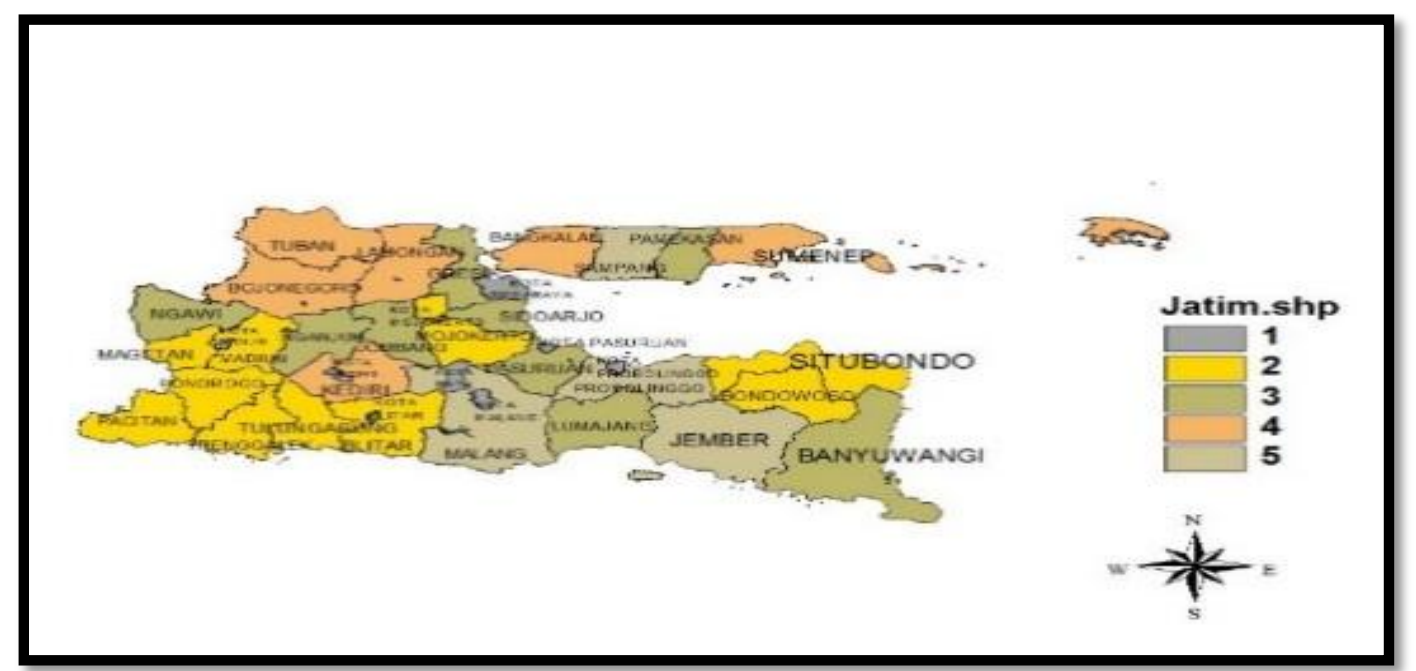

Sumber : Data sekunder diolah, Gis(2016)

\section{Gambar 4 pemetaan jumlah penduduk miskin berdasarkan kelas interval}
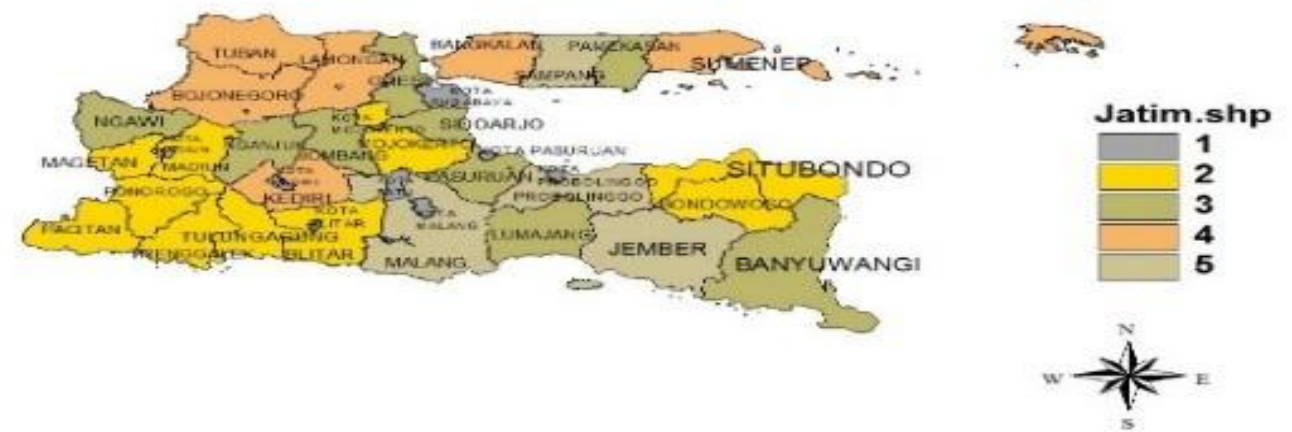

Sumber : Data sekunder diolah, Gis(2016

\section{Sedangkan pemetaan}

penduduk miskin pada tahun 2013 terlihat pada gambar 5. Kategori yang termasuk dalam kelas 1 dengan tingkat kemiskinan $(3,64 \%-4,79 \%)$ terdapat pada Kota Blitar, Kota Kediri, Kota Madiun, Kota Malang, Kota Mojokerto, Kota Pasuruan, 
Kota Probolinggo, dan Kota Batu.

Yang termasuk kelas 2 yaitu Blitar,

Bondowoso, Madiun, Magetan,

Mojokerto, Pacitan, Ponorogo,

Situbondo, Trenggalek dan

Tulungagung. Yang termasuk kelas 3

yaitu Banyuwangi, Gresik, Jombang,

Lumajang, Nganjuk, Ngawi,

Pamekasan, Pasuruan, Sidoarjo dan

Gambar 5. Pemetaan Jumlah Penduduk Miskin Berdasarkan Kelas Interval
Surabaya. Yang termasuk kelas ke 4 Bangkalan, Bojonegoro, Kediri, Lamongan, Sumenep, dan Tuban. Yang termasuk kelas ke 5 Jember, Malang, Probolinggo, dan Sampang. Berikut pemetaan jumlah penduduk miskin di Kabupaten/Kota di Provinsi Jawa Timur tahun 2014.

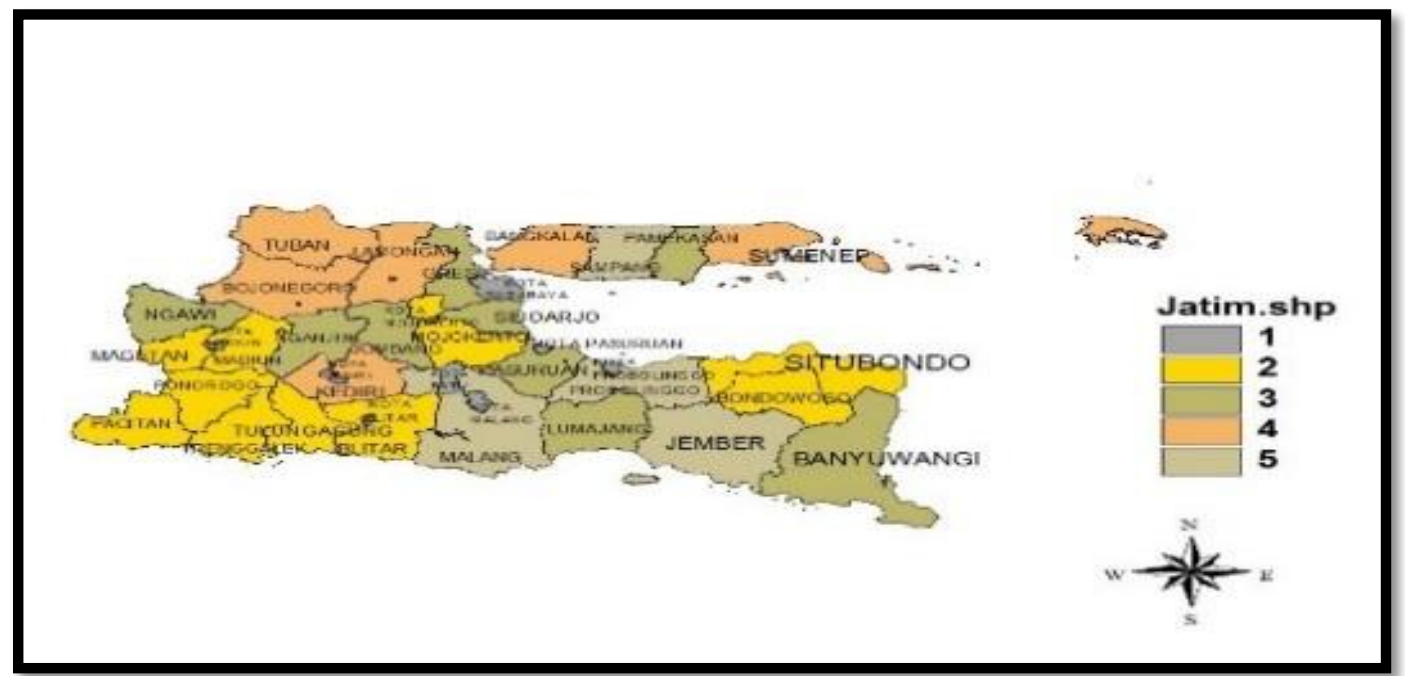

Sumber : Data sekunder diolah, Gis (2016)

Dari pemetaan jumlah penduduk miskin pada tahun 2014 yang termasuk dalam kelas 1 dengan tingkat kemiskinan $(4,80 \%-5,95 \%)$ terdapat pada Kota Blitar, Kota Kediri, Kota Madiun, Kota Malang, Kota Mojokerto, Kota Pasuruan, Kota Probolinggo, dan Kota Batu. Yang termasukkelas 2 yaitu Blitar, Bondowoso, Madiun, Magetan, Mojokerto, Pacitan, Ponorogo, Situbondo, Trenggalek dan
Pamekasan, Pasuruan, Sidoarjo dan Surabaya. Yang termasuk kelas ke 4 Bangkalan, Bojonegoro, Kediri, Lamongan, Sumenep, dan Tuban. Yang termasuk kelas ke 5 Jember, Malang, Probolinggo, dan Sampang.

Dari tahun 2010-2014 jumlah penduduk miskin di provinsi Jawa Timur tidak mengalami perubahan yang berarti. Hal tersebut dapat dilihat dari tingkat kemiskinan pada 
Pengaruh Upah Minimum dan Distribusi ..(Satria Yuda Anggriawan)

tiap-tiap kabupaten dan kota yang di gambarkan pada pemetaan berdasarkan kelas interval.

Analisis Regresi Linier Berganda dengan menggunakan Data Panel

Untuk mengetahui pengaruh Upah minimum dan distrribusi pendapatan terhadap jumlah penduduk miskin pada kabupaten/kota di Provinsi Jawa Timur dengan menggunakan analisis regresi linier berganda menggunakan software E-views 6. Data yang digunakan merupakan panel data yaitu gabungan cross-section dan time series dengan observasi 5 tahun dari tahun 2010 sampai dengan 2014 yang terdiri 38 Kabupaten/Kota di Provinsi Jawa Timur, total observasi sebanyak 190 dan hal ini memenuhi syarat untuk dilakukan analisis regresi linier berganda.

\section{Interpretasi Model}

Berdasarkan pengujian model, model commont effect merupakan yang paling baik digunakan dalam penelitian ini. Dengan menggunakan bantuan software eviews 6, diperoleh hasil output regresi panel data dengan metode fixed effect sebagai berikut:

\section{Tabel 1. Output Regresi dengan Metode Commont Effect}

\begin{tabular}{lllll}
\hline Variabel & Coefficient & Std. Error & t-Statistic & Prob. \\
\hline C & 5.013143 & 0.199080 & 25.18154 & 0.0000 \\
\hline X1 & 0.588074 & 0.123530 & 4.760585 & 0.0000 \\
\hline X2 & 0.038179 & 0.017231 & 2.215645 & 0.0282 \\
\hline
\end{tabular}

Sumber: Output regresi data panel pada eviews 6

Berdasarakan hasil uji tabel 1 maka diperoleh estimasi persamaan regresi sebagai berikut:

$\mathrm{Y}=5.013143(\log$ Kemiskinan $)+$ 0.588074 (Log Upah Minimum) $+0.038179 \quad(\log$ Distribusi Pendapatan

\section{Konstanta atau intersep}

Berdasarkan hasil estimasi data tabel 1 maka terdapat nilai konstanta sebesar Log $\mathrm{Y}=5.013143$ maka $\mathrm{Y}$ adalah anti-Log dari $5.013143=$
103072.5. Hal ini menunjukkan bahwa, jumlah penduduk miskin akan naik ketika variabel Upah Minimum dan Distribusi Pendapatan tetap.

\section{Pengaruh Upah Minimum} terhadap jumlah penduduk miskin

Dari hasil regresi pada tabel 1 dapat dijelaskan bahwa Upah Minimum berpengaruh positif dan signifikan terhadap Jumlah Penduduk Miskin pada 
kabupaten/Kota di Provinsi Jawa Timur, dengan koefisien regresi sebesar 0.588074dimana artinya jika Upah Minimum dinaikkan sebesar $1 \%$ maka akan menyebabkan kenaikan jumlah penduduk miskin pada Kabupaten/Kota di Provinsi Jawa Timur sebesar $0,59 \%$. Berdasarkan hasil penelitian, ditemukan bahwa secara langsung Upah berhubungan positif dan signifikan terhadap kemiskinan. Menurut penulis, hal ini terjadi karena sektor terbesar yang mendukung perekonomian di Provinsi Jawa Timur adalah sektor pertanian, jasa dan diikuti oleh perdagangan, dimana sektor pertanian dan jasa adalah sektor informal. Pada sektor informal masih belum bisa mensejahterakan masyarakat Jawa Timur.Jadi peneliti menemukan hubungan yang positif antara upah minimum dan kemiskinan adalah hal wajar karena mayoritas pekerjaan masyarakat Jawa Timur adalah pekerja di sektor informal dan adanya faktor biaya social inflasi. Complain terhadap inflasi adalah hal yang umum, kita tahu bahwa kenaikan dalam daya beli tenaga kerja berasal dari akumulasi modal dan kemajuan teknologi. Biasanya upah tak bergantung pada beberapa banyak uang yang dicetak pemerintah. Jika pemerintah menurunkan inflasi dengan memperlambat tingkat pertumbuhan uang. Para pekerja tidak akan melihat upah mereka naik dengan lebih cepat. Padahal ketika inflasi lebih lambat perusahaan atau sedikit menaikkan harga produk mereka setiap tahun dan akibatnya akan memberi para pekerja kenaikan upah yang lebih kecil. Menurut teori uang klasik, perubahan dalam tingkat harga keseluruhan adalah seperti perubahan dalam unit-unit ukuran.

\section{Pengaruh Distribusi Pendapatan jumlah penduduk miskin (X2)}

Dari hasil regresi pada tabel 1 dapat dijelaskan bahwa Distribusi Pendapatan berpengaruh positif dan signifikan terhadap jumlah penduduk miskin pada kabupaten/Kota di Provinsi Jawa Timur, dengan koefisien regresi sebesar 0.038179 dimana artinya jika distribusi pendapatan naek sebesar $1 \%$ maka jumlah penduduk miskin akan meningkat sebesar $1.03 \%$. dimana pengaruh antara ketimpangan distribusi pendapatan terhadap 
kemiskinan dipengaruhi oleh adanya peningkatan jumlah penduduk. Peningkatan jumlah penduduk akan berdampak negatif terhadap jumlah penduduk miskin, terutama bagi mereka yang sangat miskin. Sebagian besar keluarga miskin memiliki jumlah anggota yang keluarga yang banyak sehingga kondisi perekonomian mereka berada di garis kemiskinan semakin memburuk seiring dengan memburuknya ketimpangan pendapatan atau tingkat kesejahteraan yang menurun.

\section{a. Uji Statistik dan Pengujian Hipotesis}

Uji T Variabel Upah Minimum (X1)

Hipotesis:

H0 $: \beta 1=\beta 2=0$

H1 $: \beta 1 \neq \beta 2 \neq 0$

Keriteria pengujian:

H0 diterima jika $\mathrm{T}_{\text {hitung }}<\mathrm{T}_{\text {tabel }} \mathrm{H} 1$ diterima jika $T_{\text {hitung }}>T_{\text {tabel }}$

$\mathrm{T}_{\text {hitung }}=4.7605852$

$\mathrm{T}_{\text {tabel }}=1.65300$

Berdasarkan hasil pengamatan data diatas diketahui bahwa $\mathrm{T}_{\text {hitung }}(4,760)$ $>\mathrm{T}_{\text {tabel }}(1,653)$ dengan demikian $\mathrm{H} 1$ diterima karena $\mathrm{T}_{\text {hitung }}$ tidak berada diantara $-1,653$ sampai 1,653 yang merupakan daerah H0 diterima, artinya bahwa variabel Upah Minimum (X1) signifikan dan positif mempengaruhi Jumlah Penduduk Miskin (Y) pada tingkat kepercayaan $95 \%$.

\section{Uji $\quad \mathbf{T}$ Variabel Distribusi Pendapatan (X2)}

Hipotesis:

$\begin{array}{ll}\text { H0 } & : \beta 1=\beta 2=0 \\ \text { H1 } & : \beta 1 \neq \beta 2 \neq 0\end{array}$

Keriteria pengujian:

$\mathrm{H} 0$ diterima jika $\mathrm{T}_{\text {hitung }}<\mathrm{T}_{\text {tabel }}$

$\mathrm{H} 1$ diterima jika $\mathrm{T}_{\text {hitung }}>\mathrm{T}_{\text {tabel }}$

$\mathrm{T}_{\text {hitung }}=2.215645$

$\mathrm{T}_{\text {tabel }}=1.65300$

Berdasarkan hasil pengamatan data diatas diketahui bahwa $\mathrm{T}_{\text {hitung }}(2,215)$ $>\mathrm{T}_{\text {tabel }}(1,653)$ dengan demikian $\mathrm{H} 1$ diterima karena $\mathrm{T}_{\text {hitung }}$ tidak berada diantara $-1,653$ sampai 1,653 yang merupakan daerah $\mathrm{H} 0$ diterima, artinya bahwa variabel Distribusi Pendapatan (X2) signifikan dan positif mempengaruhi Jumlah Penduduk Miskin (Y) pada tingkat kepercayaan $95 \%$.

b. Uji F (F-test)

Pada tabel 2 diketahui bahwa $\mathrm{T}_{\text {hitung }}(11,391)>\mathrm{T}_{\text {tabel }}(1,47)$ dengan demikian $\mathrm{H} 1$ diterima karena $\mathrm{T}_{\text {hitung }}$ lebih besar dari nilai $\mathrm{T}_{\text {tabel, }}$ artinya 
Pengaruh Upah Minimum dan Distribusi ...(Satria Yuda Anggriawan)

bahwa variabel Upah Minimum mempengaruhi Jumlah Penduduk (X1), Distribusi Pendapatan (X2) Miskin (Y) pada tingkat kepercayaan secara bersama-sama signifikan $95 \%$.

Tabel 2. Uji F

\begin{tabular}{llll}
\hline R-squared & 0.132624 & Mean dependent var & 5.959201 \\
\hline Adjusted R-squared & 0.120981 & S.D. dependent var & 0.094567 \\
\hline S.E. of regression & 0.088662 & Akaike info criterion & -1.988423 \\
\hline Sum squared resid & 1.171292 & Schwarz criterion & -1.928741 \\
\hline Log likelihood & 154.1201 & Hannan-Quinn criter. & -1.964178 \\
\hline F-statistic & 11.39124 & Durbin-Watson stat & 0.492838 \\
\hline Prob(F-statistic) & 0.000025 & & \\
\hline
\end{tabular}

Sumber: Output regresi data panel pada eviews 6

$\mathrm{F}_{\text {hitung }}=11.3912$

$\mathrm{F}_{\text {tabel }}=1,47$

\section{KESIMPULAN}

\section{Uji Koefesien Determinasi $\mathbf{R}^{2}$}

Berdasarkan dari hasil

Koefisien determinasi digunakan untuk menghitung besarnya pengaruh atau kontribusi variabel bebas terhadap variabel terikat.

Tabel 3. Uji $\mathbf{R}^{2}$

\begin{tabular}{lll}
\hline Model & $\mathrm{R}^{2}$ & Adjusted R \\
\hline 1 & 0.132624 & 0.120981
\end{tabular}

Sumber: data sekunder diolah (2016) Sesuai pengamatan dan perhitungan yang terdapat pada Tabel 3maka dapat diperoleh nilai $\mathrm{R}^{2}$ $=0.120981$ yang berarti bahwa 12,09\% Jumlah Penduduk Miskin dapat menjelaskan secara bersamasama oleh Upah Minimum dan Distribusi Pendapatan, sisanya 87,9 $\%$ dipengaruhi oleh faktor-faktor lain diluar model. penelitian ini, dapat disimpulkan beberapa hal mengenai jumlah penduduk miskin pada Kabupaten/Kota di Provinsi Jawa Timur :

1. Dari hasil regresi diketahui bahwa Upah minimum memiliki nilai koefisien $\quad 103072.5 \quad$ ini menandakan bahwa setiap terjadi kenaikan Upah Minimum sebesar $1 \%$ maka jumlah penduduk miskin akan meningkat sebesar $0,58 \%$ artinya bahwa dengan kenaikan upah minimum akan meningkatkan jumlah penduduk miskin. Hal ini bila dikaitkan dengan biaya social inflasi kenaikan upah minimum seakan menjadi percuma ketika inflasi 
terus meningkat jadi hal ini bisa

dikatakan upah minimum

meningkat tingkat kesejahteraan

penduduk akan jauh lebih baik justru sebaliknya jumlah

penduduk miskin semakin

meningkat karena biaya hidup yang terus meningkat akibat inflasi.

2. Dari hasil regresi diketahui bahwa Distribusi Pendapatan memiliki nilai koefisien sebesar 0.038179 apabila naik sebesar $1 \%$ maka jumlah penduduk miskin akan meningkat sebesar $0,03 \%$. apabila ketimpangan distribusi pendapatan tinggi maka jumlah penduduk miskin akan meningkat karena dipengaruhi oleh adanya peningatan jumlah penduduk yang tiap tahun terus meningkat. Salah satu penyebab dari kemiskinan adalah ketidaksamaan pola kepemilikan sumber daya yang selanjutnya akan menimbulkan distribusi pendapatan yang timpang. 2.Dari hasil pengujian hipotesis dengan menggunakan Regresi linier berganda dapat dijelaskan bahwa Upah Minimum berpengaruh signifikan dan positif terhadap jumlah penduduk miskin pada Kabupaten/Kota di Provinsi Jawa Timur tahun 2010-2014. Sementara Variabel Distribusi Pendapatan berpengaruh signifikan dan positif terhadap jumlah penduduk miskin pada Kabupaten/Kota di Provinsi Jawa Timur tahun 2010-2014.

\section{Saran}

Berdasarkan dari kesimpulan penelitian, maka peneliti merekomendasikan berupa saransaran sebagai berikut:

1. Pada variabel upah minimum memiliki arah yang positif hal ini menunjukkan bahwa jika terjadi kenaikan pada upah minimum akan meningkatkan jumlah penduduk miskin hal ini bagi pemerintah Kabupaten/Kota di Provinsi Jawa Timur dalam menyikapinya seharusnya berhatihati terutama dalam mengambil kebijakan penetapan Upah Minimum karena akan berdampak pada tingkat kemiskinan.

2. Dari hasil regresi diketahui bahwa variabel Distribusi Pendapatan berpengaruh positif hal ini menunjukkan bahwa jika distribusi pendapatan meningkat maka kemiskinan akan meningkat 
Pengaruh Upah Minimum dan Distribusi ..(Satria Yuda Anggriawan)

dan mengalami ketimpangan

pendapatan maka pemerintah

provinsi Kabupaten/Kota di Jawa

Timur menekan seminimal

mungkin indeks rasio Gini dengan

melakukan suatu kebijakan-

kebijakan yang berdampak

kepada pemerataan pendapatan.
Dunia Ketiga . Edisi

Ketuju. Jakarta:Erlangga.

Waluyo, Dwi E, 2007. Ekonomika

Makro. Edisi Revisi.

Penerbit UMM PRESS.

\section{DAFTAR PUSTAKA}

Arsyad, Lincolin, 1999. Ekonomi Pembangunan, Edisi Keempat, Penerbit BPFEUniversitas Gajah Mada, Yogyakarta.

Badan Pusat Statistik. Provinsi Jawa Timur dalam angka 2010-2014.

Badan Pusat Statistik. 2011-2014. Susenas Maret 2015. BPS Jawa Timur.

Budiyanto, Eko. 2002. Sistem Informasi Geografis Menggunakan Arcviewa GIS. Penerbit Andi.

Gujarati, D.N, 2012, Dasar-dasar Ekonometrika,

Terjemahan Mangunsong, buku 2, Edisi 5, R.C., Salemba Empat, Jakarta

Kaufman, Bruce, 2000, The Economics of Labor Markets, Fifth Edition, The Dryden Press, New York.

Todaro, Michael P. 2000, Pembangunan Ekonomi di 
